\title{
The Enhancement of Students' Mathematical Problem Solving Ability through Contextual Approach with Bamboo Dance Technique
}

\author{
Nofriyandi \\ Department of Mathematics Education \\ Postgraduate Program \\ Indonesia University of Education (UPI) \\ Bandung, Indonesia \\ nofri_yandi86@yahoo.com
}

\author{
Tatang Herman \\ Department of Mathematics Education \\ Indonesia University of Education (UPI) \\ Bandung, Indonesia \\ tetangherman@upi.edu
}

\author{
Jarnawi Afgani Dahlan \\ Department of Mathematics Education \\ Indonesia University of Education (UPI) \\ Bandung, Indonesia \\ jarnawi@upi.edu
}

\begin{abstract}
This study is based on students' lack of ability in mathematical problem solving . To overcome such problems, a mathematics teaching and learning was conducted through learning with contextual approach by using bamboo dance technique. The study reported in this paper discusses about the enhancement of mathematical problem solving between students who were taught by contextual learning by bamboo dance technique and students who were taught by direct learning at school levels. The method of this study was quasi experimental study. The design of the study used Pre test-Posttest Control Group Design. The population of this study are $8^{\text {th }}$ grade students of Public Junior High School which consist of high, medium and low school levels. The sample of this study are all $8^{\text {th }}$ grade students at six classes which represent high, medium and low school levels at Pekanbaru. The results showed that the enhancement of mathematical problem solving ability of students who were taught by contextual approach with bamboo dance technique is higher than students who were taught by direct learning at school levels (high, medium, low), the initial mathematics ability (high, medium and low) and in general. In addition, there is no interaction between contextual approach learning with bamboo dance technique and students' school level towards the enhancement of students' mathematical problem.
\end{abstract}

Keywords-words-contextual approach; bamboo dance technique; mathematical problem solving ability

\section{INTRODUCTION}

Preparing human resources who is really outstanding and reliable in facing free competition in all sectors as a result of globalization is responsibility from all sides. In handling this, it must be done simultaneously, continuously and directly, so, we can return the glorious of our country. Good education can be viewed as an asset from strategic sectors in preparing human resources who have good morality and able to overcome every problem, that must be handled professionally. It can be proven by the improvement in education field by government, whether from the prosperity, the infrastructure or the competence. Intensive efforts in improving process quality and the educational output must be paid attention, because through education, it will be able to optimize students' potency as reliable human resources that can act and behave critical, creative, logic, and innovative in facing every problems. One of educational fields which must be given attention is mathematics education. Reference [1] stated that from the output of mathematics education, it is expected that students can have personality which is creative, critical, scientific, honest, thrift, discipline, diligence, human, just, and responsible towards their nation.

Mathematical mastery which is needed by student generally contained in goals of mathematics learning according to [2] in which one of the goal related with mathematical problem solving ability (mathematical problem solving), and so for mathematical learning goal which is written in School-based curriculum especially for Junior High School, namely, students must have ability in: (1) comprehending mathematical concept, explaining the interrelationship among concepts, and applying concept or algorithm smoothly, accurate, efficient, and appropriate in problem solving; (2) using reasoning towards pattern and nature, or explaining mathematical ideas and statements; (3) solving problems which includes ability in understanding problems, designing mathematical model, completing model and interpreting solution; (4) Communicating ideas with symbol, table, diagram, or other medias to describe situation or problems; and (5) has attitude in appreciating mathematical usage in life, namely, has curiosity, attention and interest in mathematics lesson, and diligence and confident in solving the problem.

Based on mathematical learning goals above, it is known that mathematical problems solving ability (MPSA) is one of the ability which is very important to be acquired by students. Problem solving is viewed as a process or the way which is 
done by someone in completing mathematical problem based on data and information which is known by using mathematical concept which has been studied. Students who are trained with problem solving will be skillful in selecting relevant information, analyzing and evaluating its results. In line with [3] also has view that problem solving is life skill which is important to be acquired by students which is the process consists of analysis, interpretation, prediction, evaluation, and reflection. Problem solving is one of the learning approaches which are used to stimulate students' high order thinking skills in situation which is oriented towards real world, including how to learn [4].

Based on the explanation above, the ability in problem solving must be possessed by students, so they will be accustomed in facing various problems, whether problem in mathematics, problem in other study or problem in their daily life which is more complex. Therefore, students' ability to solve mathematical problem needs to be trained so they can solve the problems which they are facing.

Discussing about mathematical achievement, Indonesia position is still below International standard. Just like reported by TIMSS international survey about $8^{\text {th }}$ grade students' mathematical and science achievement. The study result of TIMSS 2007, Indonesia is in $36^{\text {th }}$ rank from 49 countries with average score is 397 , meanwhile international score is 500 . The newest result, namely, TIMSS 2011 study result, Indonesia is in $38^{\text {th }}$ rank from 42 countries with average score is 386, meanwhile international average score is 500 [5]. If we compare with Singapore in TIMSS 2007 study result, Singapore is in the $3^{\text {rd }}$ rank with average score is 593. TIMSS 2011 study result, Singapore is in $2^{\text {nd }}$ rank with average score is 611. Similar condition is also seen from study result from PISA. In PISA 2009 study result, Indonesia is in the $61^{\text {st }}$ rank from 65 countries with average score is 371 , meanwhile international average score is 500 [6]. 2012 PISA study result, Indonesia is in $64^{\text {th }}$ rank from 65 countries with average score is 375 , meanwhile international average score is 500 [7].

Curriculum in Singapore views that the ability in mathematical problem solving is seen as the heart of mathematics [8], so, problem solving become very important ability and become the main goal in mathematics learning in Singapore. Before that, [9] has stated that problem solving ability is the heart of mathematics and can be applied in other subjects. Reference [10] stated that problem solving ability is very important in mathematics, not only for people who learn mathematics, but also for people who apply it in other subjects and in their daily life.

Based on TIMSS and PISA result, it shows that high order thinking ability of Indonesian students which one of them is problem solving is still low. Students have not had ability in solving problem non routine. Nevertheless, one thing that must be developed is high order thinking ability in mathematics.

Based on facts about learning process and result which are explained above, then in the process of mathematics teaching and learning activity, learning approach innovation is needed which emphasize on student centre in order that mathematical problem solving ability can be cultivated. One of learning which has this characteristics is contextual approach.
Mathematics learning by contextual approach is suited with the growth and development of knowledge science. Concept/knowledge which will be learned is build by students, through answer question process in the form of small group discussion, or students can be given learning material through daily problems context and its application in the form of students' worksheet which is discussed in group by teacher guidance.

The regulation of contextual learning through group discussion can be packed by bamboo dance technique. By bamboo dance technique, beside students have strength of team cooperation in group, they also demanded to understand problem/task/material which are varied in solving a problem by discussing or studying learning material more than two time. In bamboo dance technique, students are involved in verbal conflicts concerned with the opinion of their group members. Cooperative learning of bamboo dance technique is modification from small circle, big circle technique where in process of forming discussion group of small and big circle technique, students from two circles, whereas in bamboo dance technique students from group who are lined up in rows and face each other. Bamboo dance technique is developed by Anita Lie. Reference [11] revealed that this learning model give opportunity to students to share information in the concurrent time with different and regular partner.

According to Lie, cooperative learning with bamboo dance technique has some stages as follow:

1. Half of class (fourth of class if there are too many students) sit in row. Another possibility is students learn in between the chairs.

2. Half of another class learn by facing the first row.

3. Two paired groups of those two rows share the information.

4. One group move to another group in its row. By this way, each group has new partner to share. The movement can be done continually as necessary.

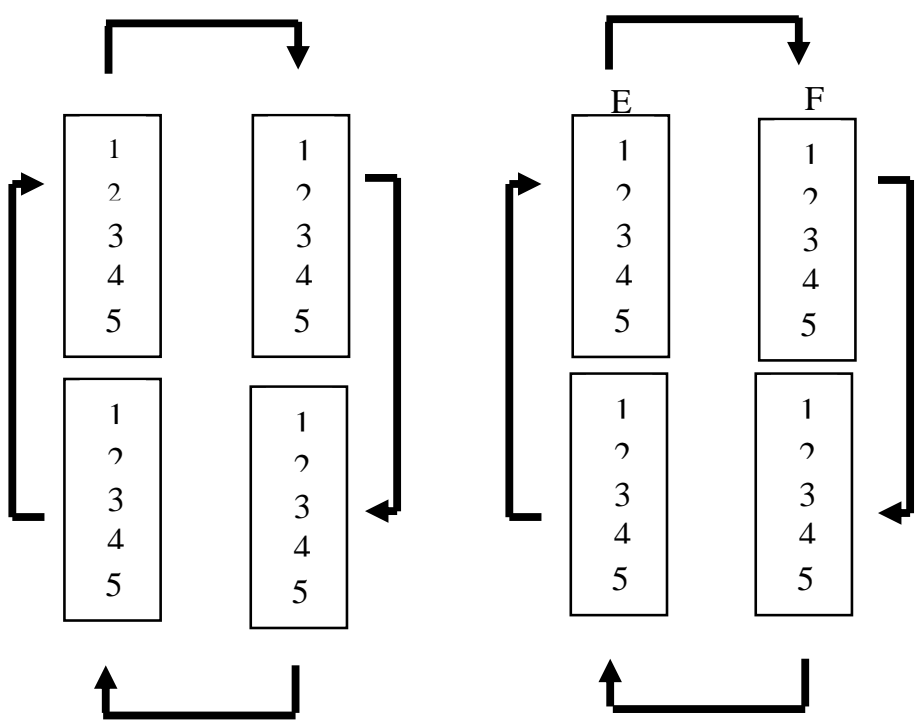

Fig 1. Group position and the way the group move in cooperative learning application with bamboo dance technique. 


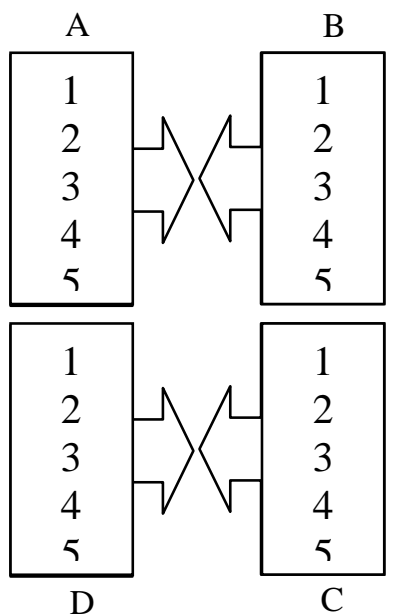

Fig. 2. Students hold discussion in their own group

\begin{tabular}{|l|l|}
\multicolumn{1}{c}{$\mathrm{A}$} & $\mathrm{B}$ \\
\hline 1 & 1 \\
2 & 2 \\
3 & 3 \\
4 & 4 \\
5 & 5 \\
\hline
\end{tabular}

\begin{tabular}{|l|l|}
\hline 1 & 1 \\
2 & 2 \\
3 & 3 \\
4 & 4 \\
5 & 5 \\
\hline $\mathrm{D}$ & $\mathrm{C}$ \\
\hline
\end{tabular}

Fig. 3. Group A join with group B and group C joint with group $\mathrm{D}$

Therefore, learning with bamboo dance technique contextual approach direct students to construct their knowledge with contextual problem. Students also demanded to be able to understand the material entirely and deliver discussion result in front of class confidently. Students who are skillful to discover the concept/knowledge make knowledge concepts which are learned by students will become more meaningful in students' memory so they are involved actively and creatively in learning process. This is parallel with Reference [1] "...... discover something by themselves can grow self confident toward themselves, can enhance motivation (included intrinsic motivation), do further examination, can grow positive attitude toward mathematics".

\section{A. Purpose and Significance of Research}

Problem solving is very important component in mathematics education. The importance of problem solving ability by students in mathematics is asserted by [12] namely: 1) problem solving ability is general aim in mathematics teaching, even as the heart of mathematics; (2) problem solving which is consist of method, procedure, and strategy is core and main process in mathematics curriculum; and (3) problem solving is basic ability in mathematics learning.

The purpose of this study was to describe the enhancement of mathematical problem solving ability (MPSA) of students who are taught by contextual approach with bamboo dance technique (CABDT) is better compared with students who is taught by direct learning (DL) which is seen from school levels (high, medium, and low) and Is there interaction between CABDT learning and SL toward MPSA enhancement.

\section{RESEARCH METHOD}

This research is a quasi experimental study, subjects are not grouped randomly, but researcher takes the subjects for granted. In this study, the researcher uses two classes which are divided into experimental class and control class. In initial stage, the researcher purposively determines school samples

from each school levels (high, medium, low). From each school, it was taken two classes randomly, one class is assigned as experimental class ant other class is assigned as control class.

Contextual approach learning with bamboo dance technique is given to students of experiment class whereas direct learning is given to control class with aim to see comparison between learning model and to see the influence of contextual approach with bamboo dance technique toward enhancement of problem solving ability in each school level.

This study used pretest-posttest control grup design, as described below [10].

$\begin{array}{lll}\mathrm{O} & \mathrm{X} & \mathrm{O} \\ \mathrm{O} & & \mathrm{O}\end{array}$

Note:

$$
\begin{aligned}
& \mathrm{X}=\mathrm{CABDT} \\
& \mathrm{O}=\text { Pretest of MPSA = Posttest of MPSA }
\end{aligned}
$$

\section{A. Population and Sample}

Population in this study are $8^{\text {th }}$ students of Public Junior High School in Pekanbaru City, Riau province in 2015/2016 academic year which consist of three school levels. high school level, medium school level, and low school level. Total of 230 students become sample in this study which consist of high school level with 66 students, medium school level with 84 students and low school level with 80 students. Each school divided into two classes namely experiment class and control class.

\section{B. Instruments}

Instrument used in this study is essay test of problem solving ability is composed of six questions.. The problems are arranged based on indicator of problem solving ability. The indicator of problem solving indicator in this study are (1) understand the problem: identify the elements known, asked, and the adequacy of element needed; (2) make/arrange mathematical model: (3) choose problem solving strategy, and (4) explain and check the correctness of answer. The material in problem solving ability test consist of two chapters namely chapter of function relation and chapter of line equation. Test in each chapter consist of three problems with high, medium and low difficulty level.

\section{RESULTS AND DISCUSSION}

\section{A. Description Data}

Result and discussion of this study are based on factors which are observed in this study. Data recapitulation of students' mathematical problem solving ability enhancement is based on school levels and learning which is consist of minimum score, maximum score, pre test average, post test average, enhancement average (n-gain) and standard deviation, can be seen in Table 1 .

Based on Table 1, it can be explained that: (a) In general, MPSA of students who are taught by contextual approach with bamboo dance technique (CABDT) is bigger compared with direct learning (DL). (b) The average enhancement of mathematical problem solving ability of students from high school level who are taught by CABDT is bigger compared 
with students who are taught by direct learning. (c) The average enhancement of mathematical problem solving ability of students from medium school level who are taught by CABDT is bigger compared with students who are taught by direct learning. (d) The average enhancement of mathematical problem solving ability of students from low school level who are taught by CABDT is bigger compared with students who are taught by direct learning. It can be concluded that from each level schools (high, medium and low), mathematical problem solving ability of students who are taught by CABDT is better than students who are taught by direct learning.

TABLE I. DATA RECAPITULATION OF STUDENTS' MPSA BASED ON SCHOOL LEVEL

\begin{tabular}{|c|c|c|c|c|c|c|c|}
\hline \multirow{2}{*}{$\begin{array}{c}\text { School } \\
\text { Level }\end{array}$} & \multirow{2}{*}{$\begin{array}{c}\text { Lear- } \\
\text { ning }\end{array}$} & \multirow{2}{*}{$\mathbf{N}$} & \multirow{2}{*}{ Data } & \multicolumn{2}{|c|}{ Score } & \multirow{2}{*}{$\begin{array}{c}\text { Avera } \\
\text { ge }\end{array}$} & \multirow{2}{*}{$\begin{array}{l}\text { Std. } \\
\text { dev }\end{array}$} \\
\hline & & & & Min & Max & & \\
\hline \multirow{6}{*}{ High } & \multirow{3}{*}{$\begin{array}{c}\text { CABD } \\
\mathrm{T}\end{array}$} & & Pre test & 6 & 42 & 20,70 & 8,97 \\
\hline & & 3 & Postest & 44 & 87 & 82,85 & 12,97 \\
\hline & & 3 & n-Gain & 0,29 & 0,84 & 0,53 & 0,15 \\
\hline & \multirow{3}{*}{ DL } & & Pre test & 6 & 40 & 20,52 & 8,41 \\
\hline & & 3 & Postest & 19 & 62 & 37,21 & 9,99 \\
\hline & & 3 & n-Gain & 0,03 & 0,46 & 0,21 & 0,12 \\
\hline \multirow{6}{*}{$\begin{array}{l}\text { Mediu } \\
\text { m }\end{array}$} & \multirow{3}{*}{$\begin{array}{c}\text { CABD } \\
\mathrm{T}\end{array}$} & & Pre test & 4 & 27 & 13,62 & 5,76 \\
\hline & & 4 & Post test & 42 & 100 & 59,74 & 10,77 \\
\hline & & 2 & $n$-Gain & 0,32 & 1,00 & 0,54 & 0,12 \\
\hline & \multirow{3}{*}{ DL } & & Pre test & 2 & 35 & 13,76 & 6,92 \\
\hline & & 4 & Post test & 17 & 67 & 31,19 & 12,23 \\
\hline & & 2 & n-Gain & 0,00 & 0,60 & 0,20 & 0,14 \\
\hline \multirow{6}{*}{ Low } & \multirow{3}{*}{$\begin{array}{c}\text { CABD } \\
\mathrm{T} \\
\end{array}$} & & Pre test & 2 & 27 & 9,95 & 5,85 \\
\hline & & 4 & Post test & 40 & 79 & 53,30 & 8,06 \\
\hline & & 0 & n-Gain & 0,32 & 0,76 & 0,48 & 0,08 \\
\hline & \multirow{3}{*}{ DL } & & Pre test & 2 & 21 & 10,72 & 4,41 \\
\hline & & 4 & Post test & 17 & 48 & 27,85 & 6,34 \\
\hline & & 0 & n-Gain & 0,05 & 0,41 & 0,19 & 0,078 \\
\hline
\end{tabular}

\section{Data Analysis}

Before conducting differentiation test of students' mathematical problem solving ability between data group, it is conducted first with normality test of data distribution using Shapiro-Wilk test and data variance homogeneity test by using Levene test for both sample group. Hypotheses are:

$\mathrm{H}_{0} \quad$ : Data of MPSA enhancement of students in each school level is normally distributed.

$\mathrm{H}_{1} \quad$ : Data of MPSA enhancement of students in each school level is abnormally distributed.

The criteria of $\mathrm{H}_{0}$ testing is accepted if probability value (sig.) is bigger than $\alpha=0,05$ and $\mathrm{H}_{0}$ is rejected if probability value is smaller than $\alpha=0,05$. The result of normality test of students' mathematical problem solving ability enhancement data based on school level and can be seen on Table II.

Based on Table II, it can be seen that students' mathematical problem solving ability which is viewed from high school level towards CABDT learning and low school level towards direct learning (DL) has sig. value bigger than $\alpha$ $=0,05$, it means that $\mathrm{H}_{0}$ is accepted. Meanwhile high school level towards direct learning, and low school level towards CABDT learning and direct learning and low school level towards CABDT learning has sig. value which is smaller than $\alpha=0,05$, it means that $\mathrm{H}_{0}$ is rejected. So, data of students' mathematical problem solving ability enhancement which is viewed from high school level towards CABDT and low school level towards direct learning is normally distributed, meanwhile data of students' mathematical problem solving ability enhancement on medium school level towards CABDT learning and direct learning and low school level towards CABDT is abnormally distributed.

TABLE II. DATA NORMALITY TEST OF STUDENTS' MPSA BASED ON SCHOOL LEVEL

\begin{tabular}{|c|c|c|c|c|}
\hline $\begin{array}{c}\text { School } \\
\text { Level }\end{array}$ & Learning & $\mathbf{N}$ & $\begin{array}{c}\text { Sig. } \\
\text { (2- } \text { tailed })\end{array}$ & Conclusion \\
\hline \multirow{2}{*}{ High } & CABDT & 33 & 0,072 & $\mathrm{H}_{0}$ is accepted \\
\cline { 2 - 5 } & DL & 33 & 0,024 & $\mathrm{H}_{0}$ is rejected \\
\hline \multirow{2}{*}{ Medium } & CABDT & 42 & 0,000 & $\mathrm{H}_{0}$ is rejected \\
\cline { 2 - 5 } & DL & 42 & 0,001 & $\mathrm{H}_{0}$ is rejected \\
\hline \multirow{2}{*}{ Low } & CABDT & 40 & 0,003 & $\mathrm{H}_{0}$ is rejected \\
\cline { 2 - 5 } & DL & 40 & 0,432 & $\mathrm{H}_{0}$ is accepted \\
\hline
\end{tabular}

Because high, medium and low school level is abnormally distributed, differentiation test is conducted, by using non parametric statistic, namely, Mann-Whitney U Hypothesis. The hypothesis testing namely:

$\mathrm{H}_{0}$ :MPSA enhancement of students who are taught by CABDT is equal with MPSA enhancement if students who are taught by direct learning.

$\mathrm{H}_{1}$ :MPSA enhancement of students who are taught by CABDT is better than MPSA enhancement of students who are taught by direct learning.

The criteria of $\mathrm{H} 0$ testing is accepted if probability value (sig.) is bigger than $\alpha=0,05$ and $\mathrm{H} 0$ is rejected if probability value is smaller than $\alpha=0,05$. The calculation result of differentiation test of students' mathematical problem solving ability enhancement based on school level and learning can be seen at Table 3 .

\section{TABLE III. THE ENHANCEMENT OF STUDENTS' MPSA BASED} ON SCHOOL LEVEL

\begin{tabular}{|c|c|c|c|c|c|}
\hline $\begin{array}{c}\text { School } \\
\text { Level }\end{array}$ & $\begin{array}{l}\text { Lear- } \\
\text { ning }\end{array}$ & $\mathbf{N}$ & $\begin{array}{c}\text { Mann- } \\
\text { Whitney } \\
\text { U Test }\end{array}$ & $\begin{array}{c}\text { Sig. } \\
(2 \text {-tailed })\end{array}$ & Conclusion \\
\hline \multirow[t]{2}{*}{ High } & CABDT & 33 & \multirow[t]{2}{*}{52,500} & \multirow[t]{2}{*}{0,000} & \multirow[t]{2}{*}{$\mathrm{H}_{0}$ is rejected } \\
\hline & DL & 33 & & & \\
\hline \multirow{2}{*}{$\begin{array}{l}\text { Medi- } \\
\text { um }\end{array}$} & CABDT & 42 & \multirow[t]{2}{*}{77,500} & \multirow[t]{2}{*}{0,000} & \multirow{2}{*}{$\mathrm{H}_{0}$ is rejected } \\
\hline & DL & 42 & & & \\
\hline \multirow[t]{2}{*}{ Low } & CABDT & 40 & \multirow[t]{2}{*}{6,000} & \multirow[t]{2}{*}{0,000} & \multirow[t]{2}{*}{$\mathrm{H}_{0}$ is rejected } \\
\hline & DL & 40 & & & \\
\hline
\end{tabular}

Based on Table 1.3 above, it can be described that data of MPSA enhancement of students who are taught by CABDT and DL towards high school level, medium school level, and low school level has sig. value which is less than $\alpha=0,05$, it means that $\mathrm{H}_{0}$ is rejected. The conclusion which is obtained from each school levels, namely, MPSA enhancement of students who are taught by CABDT is better than MPSA enhancement of students who are taught by direct learning.

To find out if there is interaction or no between learning methode and school level (high, medium and low) towards students' mathematical problem solving ability enhancement, a hypothesis is proposed as follows.

\section{Hypothesis:}

There is interaction between learning methode and school level (high, medium and low) towards students' MPSA enhancement. 
Before conducting two-way ANOVA test, it is first conducted normality test and data variance homogeneity on students' mathematical problem solving ability enhancement. Based on normality test by using shapiro-wilk test that students' mathematical problem solving ability enhancement which is viewed from high school level towards CABDT and low school level towards direct learning has sig. value bigger than $\alpha=0,05$, it means that $\mathrm{H}_{0}$ is rejected. So, $n$-Gain data of students' mathematical problem solving ability is viewed from high school level towards CABDT and low school level towards direct learning is normally distributed, meanwhile data of students' mathematical problem solving ability enhancement low school level towards CABDT learning and direct learning and low school level towards CABDT learning is normally distributed.

Because of data on students' MPSA enhancement is normally distributed, the testing uses two way ANOVA cannot be conducted, so, analysis of interaction effect between learning and direct learning towards students' mathematical problem solving ability is conducted by using Figure 4 as follows



Fig. 4. Interaction between Learning Methode and School Level towards the Enhancement of Students' Mathematical Problem Solving Ability

From Figure 4, it can be seen for school level (high, medium and low towards experimental class students is improved compared with control class. If it is ordered based on $n$-Gain average from the biggest until the smallest, for experimental class students, their orientation is medium school level, high school level and low school level students. Meanwhile, orientation towards control class in order is high, medium and low school levels students.

The similarity of average orientation on students' mathematical problem solving ability enhancement at school level (high, medium and low) towards experimental class and control class become indication that there is interaction between learning methode and school level (high, medium and low). Besides, it can be seen from the differences between the averages of students' mathematical problem solving ability enhancement. The differences of averages on students' mathematical problem solving ability enhancement between experimental class and control class in high school level is almost equal with medium and low school level.

Hypothesis Conclusion:

There is no interaction between learning methode and school level (high, medium and low) towards students' MPSA enhancement.

\section{Discussion}

The influence of learning toward MPSA enhancement also seen in each school level (high, medium and low). The average of MPSA enhancement of students who are taught by CABDT for each school level (high, medium and low) is higher than students who are taught by DL. The average of MPSA enhancement of students in high school level who are taught by CABDT is higher than students who are taught by DL. Statistically, MPSA enhancement of students in high school level who are taught by CABDT learning is better than students who are taught by DL. The average of enhancement in medium school level who are taught by CABDT learning is higher than students who are taught by DL. Statistically, it can be concluded that MPSA enhancement of students in medium school level who are taught by CABDT learning is better than students who are taught by DL. The average of enhancement for students in low school level who are taught by CABDT learning is higher than students are taught by DL learning. Based on statistic result, it can be concluded that CABDT enhancement of students in low school level who are taught by CABDT learning is better than students who are taught by DL learning.

Result of study showed that there is no interaction between students who are taught by CABDT learning and students who are taught by DL learning model and school level (high, medium and low) toward MPSA enhancement. Analysis result of figure 4 (because normality requisite is not fulfilled) showed that there is no pattern change in learning (CABDT and DL) in high school level, medium school level, and low school level categories. Because based on school level (high, medium and low) students who are taught by CABDT learning is higher than students who are taught by DL learning, then it can be concluded that CABDT learning can be applied to students who have high, medium and low initial ability. In other word, learning factor is not depended on students' school level.

\section{CONCLUSIONS}

Based on the results of this study, we draw the following conclusions: (1) The MPSA enhancement of students who are taught by CABDT based on school level (high, medium, and low) is better than students who are taught by direct learning. (2) There is no interaction between learning (CABDT and DL) and school level (high, medium and low) towards students' MPSA enhancement.

We recommend that: (1) Learning with CABDT can be made as one of mathematics learning which can be taught towards high school students, especially for school level students (high, medium and low). This learning can enhance students' creativity and activity to interact more positively with other students. (2) Learning with CABDT can be applied toward three school levels (high, medium and low) and in general with the learning to enhance students' mathematical problem solving ability. (3) By using CABDT, the teacher is expected to manage time towards learning process and to handle the problems in students' work sheet and its solving process with contextual problem. This is related to students' work sheet, in which such problem can bring up many 
mathematical concept, and can be completed with various strategies according to students' ability level.

\section{References}

[1] Ruseffendi, E.T.(1991). Pengantar kepada Membantu Guru Mengembangkan Kompetensinya dalam Pengajaran Matematika untuk meningkatkan CBSA. Bandung: Tarsito.

[2] NCTM. (2003). Program for Intial Preparation of Mathematics Specialists. $\quad$ [Online]. Tersedia: http //www.ncate.org/ProgramStandards/NCTM/NCTMELEMStandards.pdf. [1 Desember 2015].

[3] Anderson, J. (2009). Mathematics curriculum development and the role of problem solving. ACSA Conference 2009.

[4] Ibrahim, M. dan Nur, M. 2002. Pembelajaran berdasarkan masalah. Surabaya: UNESA University Press.

[5] IEA. (2012). TIMSS 2011 international result in mathematics. [Online]. Tersedia:

http://timss.bc.edu/timss2011/downloads/T11_IR_M_Chapter1.pdf [21 Desember 2015]

[6] OECD. (2010). PISA 2009 result: what students know and can do student performance in mathematics, reading and science (volume i) [Online]. Tersedia: http://www.oecd.org/pisa/pisaproducts/48852548.pdf [21 Desember 2015]

[7] OECD. (2013). PISA 2012 result: what students know and can do student performance in mathematics, reading and science (volume i) [Online]. Tersedia: http://www.oecd.org/pisa/keyfindings/pisa-2012result-volume-I.pdf [21 Desember 2015]

[8] Yee, F.P. (2002a). Using short open-ended mathematics question to promote thinking and understanding. [Online]. Tersedia: http://math.unipa.it/ grim/SiFoong. PDF. [1 Desember 2015].

[9] Yee, F.P. (2002b). The Role of Problem to Enhance Pedagogical Practice in Singapore Mathematics Classroom. The Mathematics Educator. Vol. 6, No. 2, 15-31, 2002.

[10] Abba, N. (2000). Pengembangan perangkat pembelajaran matematika berorientasi model pembelajaran berdasarkan masalah (problem-based instruction). Surabaya: Program Pascasarjana Universitas Negeri Surabaya.

[11] Ruseffendi, E.T. (2005). Dasar-dasar penelitian pendidikan dan bidang non eksakta lainnya. (edisi revisi). Bandung: Tarsito.

[12] Lie, Anita., (2008), Cooperative learning, Jakarta: Grasindo.

[13] Syaiful. (2013). The teaching model to enhance mathematical problem solving ability in junior high school teacher. International journal of education and research. Vol. 1, No. 9. 